\title{
РАЗВИТИЕ СЕЛЬСКОХОЗЯЙСТВЕННОЙ ПРОИЗВОДСТВЕННОЙ КООПЕРАЦИИ В СРЕДЕ КОЧЕВНИКОВ ГОРНОГО АЛТАЯ В 1920-E ГГ.
}

\section{DEVELOPMENT OF AGRICULTURAL PRODUCTION COOPERATION IN THE AMONG NOMADAS OF MOUNTAIN ALTAI IN THE 1920S}

\section{Katashev}

Summary: The article is devoted to the issue of participation in the agricultural production cooperation during the NEP years of the indigenous people of Altai Mountains - Altaians. It is established that in the early years of formation production cooperation in a nomadic environment, partnership initiative often came from wealthy layers nomadic community. It is concluded that the organization of cattlebreeding specialization partnerships was most responsive to the natural and traditional-historical conditions of land use of the population.

Keywords: nomadic community, new economic policy, agricultural cooperation, livestock cooperative organization, production specialization.
Каташев Максим Степанович
К.и.н., БНУ Республики Алтай «Научно-исследовательский институт алтаистики им. С.С. Суразакова»

kms_37@mail.ru

Аннотация: Статья посвящена рассмотрению вопроса участия в сельскохозяйственной производственной кооперации в годы нэпа коренного населения Горного Алтая - алтайцев. Установлено, что в первые годы становления производственной кооперации в кочевой среде, инициатива в создании товариществ зачастую исходила от зажиточных слоев кочевой общины. Сделан вывод о том, что организация товариществ животноводческой специализации в наибольшей степени отвечала природным и традиционно-историческим условиям землепользования населения.

Ключевые слова: кочевая община, новая экономическая политика, сельскохозяйственная кооперация, животноводческое товарищество, производственная направленность.
B условиях постепенного оздоровления хозяйственной жизни перед партийным руководством страны стояли задачи дальнейшего восстановления и роста сельскохозяйственного производства. Кооперация являлась одним из основных элементов проводимого большевиками нэпа. В национальных окраинах России, и в Горном Алтае, в частности, проблема восстановления хозяйственной жизни стояла особенно остро, поскольку последствия Гражданской войны самым тяжелым образом отразились на кочевом хозяйстве. На сельскохозяйственную производственную кооперацию, помимо всего, возлагалась задача укрепления хозяйственного положения алтайского населения и включения его в советскую систему хозяйствования.

Ойротская автономная область (с 1948 по 1990 гг. Горно-Алтайская автономная область в составе Алтайского края, с 1991 г. - Республика Алтай) в 1920-е годы в административно-территориальном отношении являлась частью Сибирского края. Область представляла собой отдаленный приграничный аграрный регион, народное хозяйство носило преимущественно скотоводческую направленность. Промышленное производство было представлено кустарными промыслами и мелкой крестьянской промышленностью. Значительная часть коренного населения - алтайцев - вела кочевой и полу- кочевой образ жизни. Кочевое скотоводство преобладало в центральной и в отдаленной юго-восточной частях региона. В центральных аймаках (районах) коренное население вело комплексное полукочевое скотоводческо-земледельческое хозяйствование с небольшими перекочевками, в юго-восточных - кочевое ведение хозяйства, с перемещениями на отдаленное расстояние.

История развития кооперации в Горном Алтае в первые годы нэпа получила достаточно подробное рассмотрение в отечественной историографии. В большинстве работ сибирских и горно-алтайских историков сельскохозяйственная кооперация рассматривалась в общем контексте социально-экономической истории Сибири и Горного Алтая. Среди исследований советского периода, непосредственно посвященных Горному Алтаю, первый данную тему затрагивал В.А. Демидов [10]. Автор придерживался классового подхода, однако несомненным достоинством работы является привлечение широкого комплекса архивных источников. В результате достаточно подробно представлены события, связанные с кооперативным строительством в Горном Алтае. Вместе с тем, необходимость следовать идеологическим установкам отразилась на характере оценки сложных социально-экономических процессов в алтайской деревне. Большой вклад в изучение аграрной истории Сибири в 
период с 1917 по 1937 гг. внесли новосибирские историки. Итогом их многолетнего труда стала коллективная монография «Крестьянство Сибири в период строительства социализма. 1917 - 1937 гг.» под редакторством Н.Я. Гущина [14]. Сюжеты о кооперативном строительстве в национальном селе, в том числе и в Горном Алтае в указанный период написаны Б.Б. Батуевым.

Социально-экономические процессы в горно-алтайском селе в 1920-е гг. отдельно рассматривались Н.В. Екеевым [11] Отдельное внимание автором уделено и кооперации. В дальнейшем свои выводы исследователь углубил и изложил в коллективной монографии, изданной в 2000 г. в главе, посвященной социально-экономическому развитию Горного Алтая в 1921 - 1929 гг. [13]

Новый этап рассмотрения указанной темы произошел в 2000-е гг. Большое методологическое значение имеют для нас работы А.А. Николаева. Исследователь рассмотрел в своих работах основные виды кооперации в России и в Сибири в 1920 - 1930-е гг., становление кооперативных объединений, тенденции их развития и взаимоотношения с крестьянскими хозяйствами [15; 16, C. 11-24].

Кемеровский исследователь М.В. Белозерова в своей докторской диссертации уделила большое внимание социально-экономическим процессам, происходившим в 1920-е гг. среди коренных народов Южной Сибири. Кооперацию исследователь рассматривает как один из важных инструментов интеграции коренных народов Сибири в советское общество [9].

Непосредственно процессы, связанные с кооперативным строительством в Горном Алтае, исследованы Е.М. Чедуровой. Автор подробно рассмотрела проблемы организационного становления и экономического развития разных видов кооперации в первой трети XX B. [18; 19]

Несмотря на достаточную разработанность в отечественной историографии проблем кооперативного строительства в национальных регионах Сибири, к числу которых относился и Горный Алтай, остаются слабо изученными вопросы, связанные с вовлечением в кооперацию кочевого и полукочевого населения.

В данной статье предпринята попытка рассмотреть, в какой степени сельскохозяйственная производственная кооперация способствовала развитию хозяйств кочевников в 1920-е гг.

С ростом восстановления сельского хозяйства в первые годы нэпа, в Горном Алтае, при содействии партийных и государственных властей, организуется сельскохозяйственная кооперация. Ее членами могли стать производственные кооперативы, артели, товарищества и общества, имевшие целью улучшение и развитие хозяйства, совершенствование сбыта сырья, промышленных и кустарных изделий. Сельскохозяйственная кооперация представляла собой один из инструментов воздействия Советского государства на производственные процессы распыленных мелких хозяйств [19, с. 25]. Через систему сельскохозяйственной кооперации осуществлялись заготовки, сбыт и частичная переработка крестьянской продукции, государственное кредитование крестьянства, снабжение его инвентарем, оборудованием, семенами и пр. [11, с. 20]

В середине 1920-х гг. процесс кооперирования в алтайской полукочевой общине происходил стихийно. Возникали временные объединения для проведения сезонных работ. Зачастую хозяйства алтайцев-бедняков объединялись и приобретали сельскохозяйственный инвентарь [7, л. 13об.]. Небольшие коллективы использовали разделение труда. Так, в 1926 г. в урочище Мендур-Сокконе Усть-Канского аймака (района) 6 хозяйств временно объединились в товарищество по обработке земли (ТОЗ) с распределением обязанностей: четверо глав хозяйств предоставляли лошадей, пятый - плуг, а шестой пахал небольшой участок 1-1,5 десятины [6, л. 56об.]. «Крепкие середняки» предпочитали сами вспахивать общую совместную землю. В качестве оплаты брали скот всех видов и разных возрастов, а также забирали урожай от совместного участка свыше равной доли.

В середине 1920-х гг., на начальном этапе организации в алтайской полукочевой среде производственных кооперативов, большую роль в их организации сыграли зажиточные слои. Появились простейшие коневодческие товарищества, которые в значительной степени были представлены зажиточными родовичами, а бедняков было небольшое количество. Так, в Онгудайском аймаке в 1926 г. действовали животноводческие товарищества: Сары-Кобинское (5 середняков), Усть-Киримское (2 зажиточных, 2 середняка, 1 бедняк), Елетинское (5 зажиточных, 4 середняка, 3 бедняка), Усть-Талдинское (5 середняков) [6, л. 62]. В Кырлыкском сельсовете другого национального аймака - Усть-Канского - к 1926 г. были организованы 4 машинных товарищества, которые были представлены большей частью, зажиточными хозяевами, а также 2 овцеводческих товарищества. Товарищества огораживали сенокосы, общие выгоны, занимались полеводством: закладывали огороды, выращивали овощи $[6$, л. 58, 59об.].

Предприимчивые общинники из полукочевой среды пытались активно использовать новые возможности, которые были вызваны переменами в хозяйственной жизни. Животноводческие товарищества зачастую усложняли специализацию путем расширения сферы своей производственной деятельности. Так, Куладинское то- 
варищество (Онгудайский аймак) пыталось заниматься полеводством «на культурной основе»: его члены сеяли клевер для заготовки кормов на зиму, землю удобряли навозом, привлекли агронома. Под все хозяйственные и культурно-технические мероприятия был взят кредит. Однако предпринятые усилия не увенчались успехом. Несмотря на рекомендации агронома, урожай подвергся заморозкам и погиб, пришлось возвращать денежные средства, товарищество понесло убытки. В 1925 г. в Мендур-Сокконском урочище (Усть-Канский аймак) общинники поставили перед собой довольно амбициозную задачу - организовать машинное товарищество. Инициаторами и членами будущего объединения являлись одно зажиточное хозяйство, четыре середняцкие и остальные бедняцкие и батрацкие. Однако из-за отсутствия задаточной суммы для получения кредита, реализовать идею машинного товарищества не удалось. По причине отсутствия задаточных сумм кредитные товарищества отказывали и беднякам в получении рабочего скота [6, л. 57].

Полукочевое и кочевое население организовывало товарищества животноводческой направленности, что диктовалось природными и традиционно-историческими условиями землепользования населения. Высокая товарность животноводческой отрасли создавало основу для создания низовых кооперативов скотоводческой специализации. Так, общим объем продукции животноводства в оборотах товариществ в трех национальных алтайских аймаках - Онгудайском, Усть-Канском, КошАгачском - за 1926/27-1927/28 гг. вырос в стоимостном выражении с 131,0 тыс. руб. до 279,3 тыс. руб., а ее удельный вес поднялся с 91,8 \% до 95,8 \% [5, л. 69].

Итак, в условиях роста сельскохозяйственного производства и восстановления возможностей потребительского рынка, алтайские полукочевые и кочевые хозяйства организовывались в животноводческие товарищества. Как указывают данные Ойротского облисполкома, обороты товариществ между сезонами 1926-1927 и 1927-1928 гг. стабильно росли. При этом в кочевом Кош-Агачском аймаке обороты товариществ увеличивались с большим опережением. Несмотря на географическую отдаленность от рынков сбыта и плохие транспортные пути, животноводческие товарищества в указанном аймаке за год увеличили свои обороты в 2,6 раза, тогда как в Онгудайском и в Усть-Канском - в 1,9 и в 1,8 раза соответственно.

Система полукочевого и кочевого хозяйствования традиционно опиралась на три отрасли животноводства: коневодство (занимало первенствующее место), овцеводство и разведение крупного рогатого скота. Уже в 1925 г. в районах проживания кочевого и полукочевого населения действовали 5 коневодческих товариществ: одно - в Усть-Канском аймаке (Ябоган), остальные
- в Онгудайском (Каярлык, Кеньга, Сары-Кобы). Вместе с тем, в среде русских крестьян создание коневодческих товариществ шло быстрее - в это время действовали 8 коневодческих товариществ [8, л. 79].

После окончания гражданской войны и в ходе восстановительных процессов в аграрной сфере, кочевая община алтайцев переориентировалась на овцеводство и разведение крупного рогатого скота, которое в ряде земельных обществ занимали приоритетное место в структуре ведения хозяйства.

Коневодство становилось нерентабельной отраслью, валовая доходность от него снижалась. В отчетных данных Ойротского областного земельного управления, в 1926 г., средний «прирост ценности» 4-летней лошади давал в год 8-10 руб., тогда как прирост КРС давал вдвое, а овец - в 5 раз больше капитала [1, л. 9об, 10]. Овцеводство занимало важное место в хозяйстве алтайцев, в том числе кочевников. Продукция овцеводства была представлена также и шерстью, которую использовали для продажи и для личных нужд. Овцеводство не требовало больших затрат, круглый год скот содержался на подножном корму, зимой загонялся в пригоны. При затратах на подкормку, уход и охрану от волков, доходность от одной овцы определялась в 5 руб. [1, л. 59].

Система кооперации предоставляла населению возможность реализации продукции своих хозяйств. Однако из-за низких заготовительных цен хозяева предпочитали продавать скот (лошадей и овец) частному торговцу, либо реализовывать на ближайшей железнодорожной станции - в бывшем уездном центре г. Бийске [1, л. 16].

Помимо многочисленных документальных свидетельств советских и земельных органов, о снижении значения коневодства в хозяйственной жизни кочевой общины могут косвенно свидетельствовать показатели динамики поголовья скота по основным видам на уровне аймаков. Данные Земельного управления (1924) и Отдела статистики $(1916,1929)$. Ойротского облисполкома определенно указывают на низкие темпы роста поголовья лошадей при опережающем росте поголовья стада по КРС, и особенно - по овцам и козам. Необходимо также учитывать, что в русских хозяйствах рост поголовья скота по всем видам происходил более высокими темпами, поскольку развитие животноводства в алтайских селениях серьезно сдерживалось нехваткой кормов, недооценкой теплых и просто утепленных помещений для скота $[2$, л. 57, 58].

Однако можно определенно сделать вывод о том, что население национальных алтайских аймаков предпочитало переводить свои хозяйства с коневодческого направления на овцеводство и на разведение крупного скота. Так, в «крепких» середняцких полукочевых хозяй- 
ствах урочищ Ламак и Мендур-Соккон наблюдалось снижение поголовья лошадей. За 1925-1927 гг. поголовье КРС не менялось, а овец - постепенно увеличивалось [6, л. 58]. Подобная ситуация наблюдалась во многих урочищах, где проживало полукочевое население.

О снижении значения коневодства могут свидетельствовать факты, которые партийные органы фиксировали в первых алтайских колхозах в конце 1920-х гг. Зачастую обобществлялись менее доходные отрасли хозяйства: полеводство, коневодство, и это снижало заинтересованность колхозников в работе [3, л. 70].

Со свертыванием нэпа государство стремится полностью подчинить кооперацию своему влиянию. После последнего из трех «кризисов нэпа» - «кризиса хлебозаготовок» 1927/1928 гг. партийное руководство принимает ряд решений по ужесточению давления на крестьянские хозяйства с целью изъятия «излишков» продукции. В январе 1928 г. Нарком внешней и внутренней торговли А.И. Микоян на заседании коллегии наркомата поставил вопрос о переводе закупок в сфере сельского хозяйства на систему контрактации на 1928/1929 гг. [17, с. 138-140] Сельскохозяйственные кооперативы, индивидуальные хозяйства, земельные общества переводились на контрактную основу. Государство выделяло им материальную и финансовую помощь под выполнение договора на конкретную сельскохозяйственную продукцию, с определением объемов и сроков исполнения. Тем самым, кооперативные организации получали прямую помощь от государства, но в то же время - усиливались их ответственность за выполнение договора.
Система контрактации сельскохозяйственной продукции быстро распространяется на аграрную сферу. На кооперацию стала распространяться система договоров с государством, в соответствии с которыми кооперация поставляла сырье [4, л. 34]. Летом система контрактации в стране получила законодательное оформление. В августе 1929 г. Политбюро ЦК ВКП(б) принимает решение о введении обязательной контрактации сельскохозяйственной продукции. С этого времени сельхоззаготовки перешли на плановую основу и вошла в систему госзаданий. Кооперация стала превращаться в инструмент государственного вмешательства в аграрную сферу.

Таким образом, кооперация послужила средством, которое государство использовало для интеграции кочевого и полукочевого населения в структуру советского общества. В первые годы нэпа алтайцы слабо включались в кооперативное строительство. Полукочевое и кочевое население придерживалось привычных форм хозяйствования. Алтайское население рассматривало участие в сельскохозяйственной кооперации как возможность для укрепления своих скотоводческих хозяйств. На начальном этапе производственной кооперации инициатива в создании простейших животноводческих товариществ и товариществ по обработке земли принадлежала зажиточным слоям алтайской полукочевой общины. Традиционная отрасль кочевого хозяйства - коневодство - стало утрачивать свое первенствующее значение ввиду слабой рентабельности, кочевые хозяйства предпочитали специализироваться на разведении крупного рогатого скота. К концу 1920-х гг. кооперация все больше подпадала в зависимое положение по отношению к государственным структурам.

\section{ЛИТЕРАТУРА}

1. Российский государственный архив экономики (РГАЭ). Ф. 478. Оп. 5. Д. 2718.

2. Государственный архив социально-правовой документации (ГАСПД РА). Ф. П-1. ОП. 1. Д. 329.

3. ГАСПДРА. Ф. П-1. ОП. 1. Д. 532.

4. ГАСПД РА. Ф.Р-33. ОП. 1. Д. 133

5. ГАСПД РА. Ф. Р-33. ОП. 1. Д. 145.

6. ГАСПДРА. Ф. Р-42. 0п. 1. Д. 44.

7. ГАСПДРА. Ф.Р-42.0П. 1.Д. 173.

8. ГАСПД РА. Ф. Р-42. ОП. 1.Д. 206.

9. Белозерова М.В. Проблемы интеграции и национального самоопределения коренных народов Южной Сибири (1920-е гг. - начало XXI в.): автореф. дис. на соиск. учен. степ. д.-ра. ист. наук; Том. гос. ун.-т. Томск, 2008. 55 с

10. Демидов В.А. К социализму, минуя капитализм. Очерк социалистического строительства в Горно-Алтайской авт. обл. Новосибирск: Наука, Сиб. отд-ние, 1970. 224 C.

11. Екеев Н.В. Социально-экономическое развитие деревни Горного Алтая в 1920-х годах. Горно-Алтайск: Горно-Алтайское отделение Алтайского книжного издательства, 1988. 208 с.

12. Жданова Н.С. Сельскохозяйственная кредитная кооперация на Алтае в 1920-е гг. автореф. дисс. на соиск. уч. степ. к. ист. н. Барнаул, 2015.24 с.

13. История Горного Алтая. В 3 т. Т. 2. 1900 - 1945 гг. / под ред. Н. М. Екеевой, Н.Ф. Иванцовой. Бийск: Изд.--во БиГПИ, 2000. 223 с.

14. Крестьянство Сибири в период строительства социализма. 1917 - 1937 гг. Новосибирск: Наука, 1983. 389 с.

15. Николаев А.А. Основные виды кооперации в России: историко-теоретический очерк. Новосибирск: Сибпринт, 2007. 280 с.

16. Сельское хозяйство Сибири в XX веке: проблемы развития и кризисы / отв. ред. В.А. Ильиных, О.К. Кавцевич. Новосибирск: Сибпринт, 2012.408 с. 
17. Трагедия советской деревни. Коллективизация и раскулачивание. 1927-1939. Документы и материалы. В 5-ти тт. / Т. 1. Май 1927 - ноябрь 1929 / Под ред.: В. Данилова, Р. Маннинг. М.: Российская политическая энциклопедия (РОССПЭН), 1999.880 с.

18. Чедурова Е.М. Кооперация Западной Сибири и ее роль в развитии аграрных технологий (1906 - 1971 гг.). Бийск: Изд-во БГПУ, 2003.150 с

19. Чедурова Е.М. Сельская кооперация Горного Алтая в 20-е годы XX в. // Национальный регион России в эпоху революционных преобразований и становления политической системы сталинизма. 1917 - 1939 гг. (на примере Ойротии - Горного Алтая): Матер. межрег. науч.-практ. конф. /Редколл.: к. ист. н. Н.В. Екеев (отв. ред.), к. ист. н. М.С. Каташев, к. полит. н. Г. Б. Эшматова; БНУ РА «НИИ алтаистики им. С.С. Суразакова». Горно-Алтайск-Бийск: Общероссийское литературное общество, 2018. С. 20-29.

() Каташев Максим Степанович (kms_37@mail.ru).

Журнал «Современная наука: актуальные проблемы теории и практики»

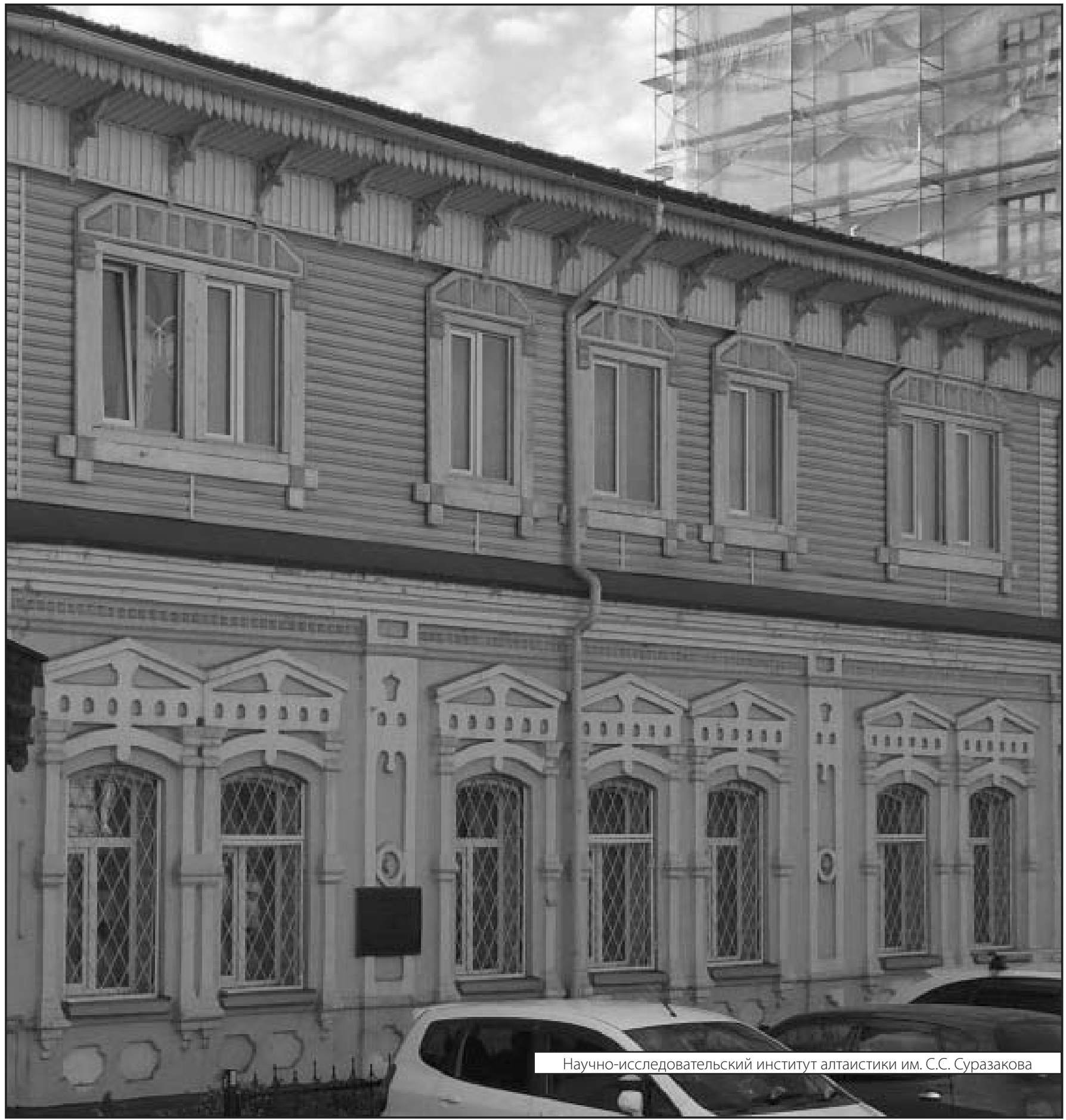

